\title{
PŘÍRODA
}

7:1-200, 2005

ISSN 1212-4117

\section{Josef Šmajs}

Masarykova univerzita v Brně, Filosofická fakulta

Přirozenou evolucí vytvořený vesmír včetně živé planety Země, proces i výsledek aktivity velkého třesku. Obvykle se $\mathbf{P}$ chápe jako to, co vzniklo prirozeně, tj. opak kultury, nebo jen jako protiklad kultury duchovní (lidského ducha, aktivity). Někdy se pojmem $\mathbf{P}$ rozumí celá objektivní realita zahrnující i lidskou společnost, tj. i tzv. „druhou prírodu“. Dnes používaný pojem prírody je však nejen neurčitý, ale i obsahově nesprávný. V pojetí jeho obsahu se zamlčuje, že Země souvisí s vesmírem a že člověk jako biologický druh je prvkem živé pozemské $\mathbf{P}$, že je organismem, úzce svázaným s ostatními živými systémy biosféry. Nerespektuje se poznatek, že pouze biosféra jako celek je nejmenším relativně autonomním systémem schopným dlouhodobého vzestupného vývoje v čase. Všechny subsystémy biosféry, jedinci, populace, druhy, biocenózy, jsou totiž dočasné a nesamostatné, závislé na struktuře, integritě a prosperitě biotického celku.

Pojem $\mathbf{P}$ je jedním z nejstarších filosofických pojmů vůbec. Starořecký pojem „,fysis“ byl pojmem každodenního života, označoval to, co se zrodilo prirozeně, co nevzniklo lidskou aktivitou. Podobně byl chápán i latinský pojem „natura“. Středověk interpretoval prrírodu jako stvořenou Bohem. V renesančním myšlení došlo sice k oživení teoretického zájmu o $\mathbf{P}$ a člověka, ale pojem $\mathbf{P}$ nezískal vyhraněný teoretický obsah. Naopak, v důsledku vysoké prestiže newtonovské fyziky se od konce 17 . století z teoretického myšlení vytrácel. Zdálo se, že jako pojem, který svým etymologickým kořenem odkazoval k rození a vznikání, dosloužil. Také vlivem Descartova dualismu člověka a $\mathbf{P}$ se rozšiřovala iluze, že člověk, který přírodu poznává a přetváŕí, k ní nenáleží, že je prírodě nadřazen. $\mathbf{P}$ byla pojata jako rozprostraněnost, jako nezničitelná hmotnost a energie, tj. perpetuum mobile, $\mathrm{v}$ němž nic onticky nového nevzniká. Pojem $\mathbf{P}$ se začal rozpouštět $\mathrm{v}$ ontologicky důležitějším pojmu hmoty.

Rozvoj mechanické techniky po průmyslové revoluci posiloval názor, že povahu prrírodních dějů nejlépe postihuje exaktní prrírodní věda o neživém světě - s matematikou spolupracující fyzika. Ale kategorie fyziky jako např. těleso, síla, pohyb, dráha, zrychlení atp., které byly srozumi- telné i pro běžné myšlení, redukovaly $\mathbf{P}$ na tělesa pohybující se v prostoru, na mechanismus bez minulosti, vlastní ontické tvořivosti a hodnoty. Důraz na zákon zachování hmotnosti a energie, vyjádřený známým Einsteinovým vztahem $\mathrm{E}=\mathrm{mc}^{2}$, zakryl fakt přirozené evoluce vesmíru, tj. nevratnost času a nezachovávání struktur.

Požadavek ustavení adekvátní antropologie i řešení konfliktu kultury s př́rodou vyvolávají potřebu definovat prrírodu evolučně ontologickým způsobem. Nejen jako člověku vnější předmětnost, ale také jako člověka zahrnující procesualitu a nevratný evoluční čas: nejdůležitější konstitutivní faktor dnešní podoby $\mathbf{P}$. Má-li totiž spontánně tvořivá aktivita vesmíru (přirozená evoluce) nějaký hlubší smysl, pak je to výstavba jeho velkolepé struktury, tvorba jeho nepředstavitelně rozsáhlé fyzické uspořádanosti, která zahrnuje také veškerou uspořádanost skrytou. K té např̀. patř́ pravidla utváření neživých struktur, genetická pamět' biosféry včetně genetické paměti člověka jako biologického druhu.

Máme-li nynější neurčitý pojem $\mathbf{P}$ teoreticky i hodnotově rehabilitovat, je nezbytné v něm rozlišit dvě obsahové vrstvy: $\mathbf{P}$ v širším smyslu - kosmos - a $\mathbf{P}$ v užším smyslu - pozemskou. Toto rozlišení pak umožňuje novou odpověd' na starou antickou a středověkou otázku: Jaké je postavení Země ve vesmíru? Odpovědět lze jak z tradičního hlediska fyzikálně mechanického, tak z nového pohledu evolučně ontologického.

První odpověd', která překonává antický a středověký geocentrismus a která je stále ještě považována za vrcholný výkon vědeckého poznání, lze shrnout takto: Země je planetou Slunce, tj. hvězdy druhé generace; není nepohyblivým středem sluneční soustavy, středem galaxie ani kosmu; není vůbec žádným prostorově významným bodem vesmíru. I naše Slunce je jen nepatrnou a nevýznamnou součástí kosmu, který jako celek, tj. ve velkém měřítku, je homogenní a izotropní, tj. ve všech směrech stejný, a který se skládá nejen z vodíku a hélia, ale i z nepatrného množství dalších prvků, jaké nacházíme na Zemi; okolní kosmos však není oživený, dosud poznaný vesmír je bez života. 
Druhá, evolučně ontologická odpověd’ na stejnou otázku zdánlivě popírá již uvedenou fyzikálně mechanickou charakteristiku Země. Jakoby oživuje starý geocentrismus, protože pozemské pŕírodě znovu navrací to, co jí bylo newtonovskou fyzikou neprávem odňato: výjimečnost, tvorrivost, usporrádanost. Představuje Zemi jako evolučně vzniklý systémem živých a neživých prvků a subsystémů, jako strukturu sourodou s člověkem, jako jediný možný domov člověka a lidské kultury.

$\mathrm{S}$ prostorově nevýznamným postavením Země ve vesmíru bylo totiž spojeno úzké pásmo podmínek, které umožnily vznik života a jeho dostatečně dlouhý, nikdy zcela nepřerušený vývoj. Kosmologie, termodynamika nelineárních systémů, synergetika a další vědy prínesly důkaz, že dnešní vesmír byl formován jednak ochlazováním a ředěním původně stlačené vesmírné aktivity, a jednak protisměrným procesem její spontánní samoorganizace. Struktura dnešního vesmíru vznikala tedy postupně, zvláštní kondenzací jeho počáteční aktivity, původně horké, koncentrované v singularitě a nerozdělené na látku a záření.

S vesmírným vývojem souvisí i vývoj planetárního života, který závisí na spolehlivé funkcí pro Zemi relativně blízkého termojaderného reaktoru - našeho Slunce. Biosféra je totiž otevřeným nelineárním systémem napájeným sluneční energií, je pokračováním vývoje přirozené abiotické evoluce vesmírné. Organizační složitost biosféry narůstala postupně, tempem, které patrně nemohlo být vyšší, nebot' souviselo jak s víceméně konstantním př́k konem zárivé sluneční energie, tak s vysokou spolehlivostí přenosu genetické informace. Evoluce totiž využívá také nespolehlivosti prrirozeného informačního přenosu.

Právě proto jsou dnešní organismy živou historickou pamětí dlouhého vývoje biosféry. Jsou jakoby nositeli její „duchovní i materiální kultury“ současně. Evoluční podmínky se totiž nejen informačně zapsaly v jejich genomech, nýbrž se také ztělesnily v jejich orgánech, tkáních a strukturách. Proto k probuzení lidské odpovědnosti za všechny kulturou vyhubené či ohrožené druhy, pro uctivý vztah člověka $\mathrm{k}$ Zemi existují také pádné argumenty informační.

Pozemský život je jediným velkým organismem, jehož jsme součástí a jehož ,zdravotní stav“ je dnes z naší viny kritický. Zničením většiny původních ekosystémů jsme vážně poškodili nejen fyzickou strukturu pozemského života, nýbrž i jeho pamět', jeho strukturu informační. Zničili jsme část genetické informace dnešní biosféry, jediné nositelky jeho vnitřní konstitutivní informace. Poškodili jsme vzácnou pamět' živé prúrody, která vznikala a integrovala život dávno před tím, než se na Zemi objevil náš biologický druh. A protože genetická informace tvoří neviditelný implikátní řád planetárního života, protože funguje jako jeho bariéra proti rozpadu, nebezpečí, které nám hrozí, je v celé dosavadní lidské historii nejvážnější.

Přirozená informace je totiž lidskému životu i lidské sociokulturní informaci absolutně nadřazená. Ve světě, v němž onticky tvořivá evoluce probíhá na pozadí procesu všeobecného rozpadu, je přirozená informace indikátorem vývoje života: samovolně se rozvijí i upadá, část její struktury může být zničena prírodní katastrofou či kulturou, ale ve svém celku je nesmrtelná jako život sám. Člověk, prvek života je naopak smrtelný nejen jako individuum, ale i jako druh - bez člověka je smrtelné i lidské dílo. Žádný vědecký objev, žádné umělecké či technické výtvory pozemský život bez člověka využívat a rozvíjet nemůže. Zánikem člověka podlehne lidská kultura entropii, pririrozenému rozpadu. 